\title{
Measuring health inequalities: a systematic review of widely used indicators and topics
}

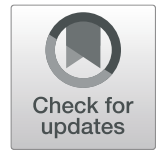

Sergi Albert-Ballestar ${ }^{1,2}$ and Anna García-Altés 1,2,3* $^{*}$

\begin{abstract}
Background: According to many conceptual frameworks, the first step in the monitoring cycle of health inequalities is the selection of relevant topics and indicators. However, some difficulties may arise during this selection process due to a high variety of contextual factors that may influence this step. In order to help accomplish this task successfully, a comprehensive review of the most common topics and indicators for measuring and monitoring health inequalities in countries/regions with similar socioeconomic and political status as Catalonia was performed.

Methods: We describe the processes and criteria used for selecting health indicators from reports, studies, and databases focusing on health inequalities. We also describe how they were grouped into well-known health topics. The topics were filtered and ranked by the number of indicators they accounted for.

Results: We found 691 indicators used in the study of health inequalities. The indicators were grouped into 120 topics, 34 of which were selected for having five indicators or more. Most commonly found topics in the list include "Life expectancy", "Infant mortality", "Obesity and overweight (BMI)", "Mortality rate", "Regular smokers/ tobacco consumption", "Self-perceived health", "Unemployment", "Mental well-being", "Cardiovascular disease/ hypertension", "Socioeconomic status (SES)/material deprivation".

Conclusions: A wide variety of indicators and topics for the study of health inequalities exist across different countries and organisations, although there are some clear commonalities. Reviewing the use of health indicators is a key step to know the current state of the study of health inequalities and may show how to lead the way in understanding how to overcome them.
\end{abstract}

Keywords: Health inequalities, Health indicators, Review, Health policy

\section{Introduction}

Strong efforts to tackle health inequalities can be seen at international and national level since the 1980s. In early 2008, the World Health Organization's (WHO) Global Commission on Social Determinants of Health called for action on the social determinants of health, the conditions in which persons are born, grow, work, live, and age, to "close the gap in a generation" [1]. In late 2008,

\footnotetext{
* Correspondence: agarciaaltes@gencat.cat

${ }^{1}$ Catalan Health System Observatory, Agència de Qualitat i Avaluació

Sanitàries de Catalunya (AQuAS), 81-95 (2a planta), 08005 Barcelona, Spain

${ }^{2}$ CIBER de Epidemiología y Salud Pública (CIBERESP), Barcelona, Spain

Full list of author information is available at the end of the article
}

the Spanish Public Health General Direction (Dirección General de Salud Pública) and the Foreign Health of Health Ministry and Social Policy (Sanidad Exterior del Ministerio de Sanidad y Politica Social) requested the constitution of the Commission for the Reduction of Social and Health Inequalities (Comisión para Reducir las Desigualdades Sociales en Salud en España (CRDSSE) [2]. The mission of CRDSS-E was to elaborate on a proposal of intervention measures to reduce health inequalities. The CRDSS-E published two documents: one analysing health inequalities in the Spanish context [3], and another describing some policy proposals to tackle them [4]. In 2011, a total of 125 countries, Spain being

\section{$\triangle B M C$}

(C) The Author(s). 2021 Open Access This article is licensed under a Creative Commons Attribution 4.0 International License, which permits use, sharing, adaptation, distribution and reproduction in any medium or format, as long as you give appropriate credit to the original author(s) and the source, provide a link to the Creative Commons licence, and indicate if changes were made. The images or other third party material in this article are included in the article's Creative Commons licence, unless indicated otherwise in a credit line to the material. If material is not included in the article's Creative Commons licence and your intended use is not permitted by statutory regulation or exceeds the permitted use, you will need to obtain permission directly from the copyright holder. To view a copy of this licence, visit http://creativecommons.org/licenses/by/4.0/ The Creative Commons Public Domain Dedication waiver (http://creativecommons.org/publicdomain/zero/1.0/) applies to the data made available in this article, unless otherwise stated in a credit line to the data. 
one of them, developed and signed the Rio Political Declaration on Social Determinants of Health [5]. The declaration recommended interventions from governments and international organisations [6].

At a regional level in Catalonia, tackling health inequalities is one of the main goals of both the Catalan Health Plan 2016-2020 (led by the Health Department of the Catalan Government) [7] and the Interdepartmental and Intersectorial Public Health Plan 2017-2020 (PINSAP) [8, 9]. During the past years, various reports and peerreviewed papers about the health effects of the economic crisis on the population of Catalonia were published by the Catalan Health System Observatory [10-17].

Overall, much effort has been devoted to monitoring and tackling health inequalities at regional, national, and international levels. Even so, OECD countries continue to present large disparities in health, including, for example, significant differences in life expectancy between people with the highest and lowest levels of education [18]. The selection of topics represents the first step in monitoring health inequalities according to many conceptual frameworks and is highly relevant, as these topics will potentially limit the detection of health inequalities within the population, hence playing a key role in providing evidence for posterior decision-making [19, 20]. Yet some difficulties may arise during the selection of relevant topics, as well as their health indicators. A wide diversity of indicators for monitoring health inequalities have been used across different countries and organisations; this is due to the high variety of contextual factors that may have an influence on it, such as the study goals or the information resources available.

In order to help accomplish this task successfully, the objective of this study is to perform a systematic review of the most common topics and indicators used for measuring and monitoring health inequalities in the reports, projects, and databases of international, national, and regional governmental organizations.

The main purpose of this study is to provide a broad overview of health inequalities topics considered relevant by different public health organizations. Nevertheless, the focus of this review is on countries/regions with similar socioeconomic and political status to Catalonia. It may also be useful for other organizations who decide to study or monitor health inequalities to accomplish its very first step: topic selection. In addition, gaining some insights about which health issues are being prioritized, as well as which indicators were used, are considered secondary goals.

\section{Material and methods}

First, a bibliographic search was performed using PubMed, Google Scholar, and Google search engine with the terms "health inequalities", "health observatories" and "health inequalities indicators". Occasionally, names of concrete regions, countries, or organisations were added to these terms (i.e., "Andalucia health observatory" or "Canada health inequalities"). The search was performed from March to June of 2019. Once finished, a set of inclusion criteria was applied; studies included in the review had to:

1. Include health inequalities indicators: All the reports that contained no health indicators were automatically discarded (i.e., policy frameworks [21]).

2. Have been carried out by a governmental organisation or a related entity, whether at an international, national, or regional level: the reports not published by governmental (or government-related) organisations were discarded.

\section{Have a socioeconomic and political status} similar (or highly related) to Catalonia: some reports were discarded due to significant differences in the socioeconomic profile of the countries they were studying in comparison to Catalonia or Spain.

Once the reports were selected, the authors performed a quality control check of the indicators shown in the reports and databases. The indicators had to match the basic anatomy of an indicator as a minimum requirement to be considered an indicator. This basic anatomy consists of containing data, i.e. the numerical data input; and containing good metadata, like a title and an explanation of how an indicator is defined and calculated [22]. In addition, the different reports found were classified according to the geo-political region they were studying: 1 . international, 2 . national, and 3. regional (Table 1).

After this selection process, the indicators were grouped into topics by semantic matching of their definition as well as by the area of knowledge there are intended to measure. Most of the topics were supported by references of relevant organisations like the WHO or the United Nations (UN) (see Table 2). Each topic was uniquely named in accordance with the area of knowledge that instruments were intended to measure. Indicators from different sources were often merged due to high similarities between them (most commonly, the only differences were stratifiers such as age, gender or region). Every topic had to be formed by at least five indicators in order to be considered relevant enough; the topics with less than five indicators were discarded.

The search was performed by the two researchers, and the results shared in order to agree on any discrepancies. All the data was organised in spreadsheets to identify common indicators, and then sorted by the amount of 
Table 1 Reports and datasets identified in the search

\begin{tabular}{|c|c|c|c|c|c|}
\hline Type & $\begin{array}{l}\text { Organisation/ } \\
\text { Institution }\end{array}$ & Report or database title & $\begin{array}{l}\text { Number } \\
\text { of } \\
\text { indicators }\end{array}$ & URL for website or PDF & Reference \\
\hline International & $\begin{array}{l}\text { WHO Regional Office } \\
\text { for Europe }\end{array}$ & Data Management Tool & 6 & $\begin{array}{l}\text { http://dmt.euro.who.int/classifications/tree/ } \\
\text { B\#B03 }\end{array}$ & {$[28]$} \\
\hline International & European Commission & Health inequalities in the EU & 12 & $\begin{array}{l}\text { https://ec.europa.eu/health/sites/health/files/ } \\
\text { social_determinants/docs/ } \\
\text { healthinequalitiesineu_2013_en.pdf }\end{array}$ & {$[25]$} \\
\hline International & $\begin{array}{l}\text { Social Protection } \\
\text { Committee Indicators } \\
\text { Sub-group (European } \\
\text { Commission) }\end{array}$ & $\begin{array}{l}\text { Portfolio of EU Social Indicators for the } \\
\text { Monitoring of Progress Towards the EU } \\
\text { Objectives for Social Protection and } \\
\text { Social Inclusion }\end{array}$ & 12 & $\begin{array}{l}\text { https://ec.europa.eu/social/ } \\
\text { BlobServlet?docld=14239\&langld=en }\end{array}$ & {$[26]$} \\
\hline International & $\begin{array}{l}\text { Various organisations } \\
\text { (European } \\
\text { Commission funded } \\
\text { project) }\end{array}$ & I2SARE & 37 & $\begin{array}{l}\text { https://www.sergas.es/Saude-publica/-12 } \\
\text { SARE-Galicia }\end{array}$ & {$[27]$} \\
\hline International & European Commission & $\begin{array}{l}\text { European Core Health Indicators } \\
(\mathrm{ECHI})^{*}\end{array}$ & 64 & $\begin{array}{l}\text { https://ec.europa.eu/health/indicators/echi/ } \\
\text { list_en\#id3 }\end{array}$ & [24] \\
\hline International & European Commission & Eurostat (SDG) & 13 & $\begin{array}{l}\text { https://ec.europa.eu/eurostat/web/sdi/good- } \\
\text { health-and-well-being }\end{array}$ & [23] \\
\hline International & The World Bank & $\begin{array}{l}\text { World Bank Open Data (Indicators } \\
\text { section) }\end{array}$ & 52 & https://data.worldbank.org/indicator/ & {$[30]$} \\
\hline International & WHO & $\begin{array}{l}100 \text { Core Health Indicators (plus health- } \\
\text { related SDGs) } 2018\end{array}$ & 100 & $\begin{array}{l}\text { https://www.who.int/healthinfo/indicators/1 } \\
\text { 00CoreHealthlndicators_2018_infographic. } \\
\text { pdf?ua=1 }\end{array}$ & [29] \\
\hline National & $\begin{array}{l}\text { Institute of Health } \\
\text { Equity }\end{array}$ & Marmot Indicators Release 2017 & 10 & $\begin{array}{l}\text { http://www.instituteofhealthequity.org/ } \\
\text { about-our-work/marmot-indicators-release-2 } \\
017\end{array}$ & {$[35]$} \\
\hline National & $\begin{array}{l}\text { Canadian Institute for } \\
\text { Health Information }\end{array}$ & Health Inequalities Map & 105 & $\begin{array}{l}\text { https://infobase.phac-aspc.gc.ca/health- } \\
\text { inequalities/docs/health-inequalities-map-en. } \\
\text { pdf }\end{array}$ & [34] \\
\hline National & $\begin{array}{l}\text { Public Health Agency } \\
\text { of Canada (PHAC) }\end{array}$ & $\begin{array}{l}\text { Key Health Inequalities in Canada: A } \\
\text { National Portrait - Executive Summary }\end{array}$ & 22 & $\begin{array}{l}\text { https://www.canada.ca/en/public-health/ } \\
\text { services/publications/science-research-data/ } \\
\text { key-health-inequalities-canada-national- } \\
\text { portrait-executive-summary.html }\end{array}$ & [33] \\
\hline National & $\begin{array}{l}\text { Government of } \\
\text { Scotland }\end{array}$ & $\begin{array}{l}\text { Long-term monitoring of health } \\
\text { inequalities: December } 2018 \text { report }\end{array}$ & 14 & $\begin{array}{l}\text { https://www2.gov.scot/Publications/201 } \\
\text { 8/12/8085 }\end{array}$ & {$[37]$} \\
\hline National & $\begin{array}{l}\text { National Health } \\
\text { Service (England) }\end{array}$ & $\begin{array}{l}\text { England Analysis: NHS Outcome } \\
\text { Framework Health Inequalities } \\
\text { Indicators 2016/17 }\end{array}$ & 30 & $\begin{array}{l}\text { https://www.england.nhs.uk/wp-content/ } \\
\text { uploads/2017/07/nhs-outcome-framework- } \\
\text { health-inequalities-indicators-2016-17.pdf }\end{array}$ & [36] \\
\hline National & $\begin{array}{l}\text { Institut d'Estadística } \\
\text { d'Andorra }\end{array}$ & Observatori Social d'Andorra & 13 & https://observatorisocial.ad/ & {$[31]$} \\
\hline National & $\begin{array}{l}\text { Australian Institute of } \\
\text { Health and Welfare }\end{array}$ & $\begin{array}{l}\text { Health inequalities in Australia: } \\
\text { morbidity, health behaviours, risk } \\
\text { factors, and health service use }\end{array}$ & 20 & $\begin{array}{l}\text { https://www.aihw.gov.au/getmedia/0cbc6 } \\
\text { c45-b97a-44f7-ad1f-2517a1f0378c/ } \\
\text { hiamhbrfhsu.pdf }\end{array}$ & {$[32]$} \\
\hline National & $\begin{array}{l}\text { WHO Regional Office } \\
\text { for Europe }\end{array}$ & Health Inequalities in Slovenia & 32 & $\begin{array}{l}\text { http://www.euro.who.int/_data/assets/pdf_ } \\
\text { file/0008/131759/Health_inequalities_in_ } \\
\text { Slovenia.pdf }\end{array}$ & {$[38]$} \\
\hline National & $\begin{array}{l}\text { Instituto Nacional de } \\
\text { Estadistica (Portugal) }\end{array}$ & Indicadores Sociais - 2011 & 16 & $\begin{array}{l}\text { https://censos.ine.pt/xportal/xmain?xpid= } \\
\text { INE\&xpgid=ine_ } \\
\text { publicacoes\&PUBLICACOESpub_boui=1492 } \\
\text { 79938\&PUBLICACOEStema=5553 } \\
\text { 8\&PUBLICACOESmodo=2 }\end{array}$ & {$[40]$} \\
\hline National & $\begin{array}{l}\text { Ministry of Health and } \\
\text { Social Policy of Spain }\end{array}$ & $\begin{array}{l}\text { Moving Dorward Equity in Health: } \\
\text { Monitoring Social Determinants of } \\
\text { Health and the Reduction of Health } \\
\text { Inequalities }\end{array}$ & 30 & $\begin{array}{l}\text { https://www.mscbs.gob.es/profesionales/ } \\
\text { saludPublica/prevPromocion/promocion/ } \\
\text { desigualdadSalud/PresidenciaUE_2010/ } \\
\text { conferenciaExpertos/docs/ } \\
\text { haciaLaEquidadEnSalud_en.pdf }\end{array}$ & [39] \\
\hline
\end{tabular}


Table 1 Reports and datasets identified in the search (Continued)

\begin{tabular}{|c|c|c|c|c|c|}
\hline Type & $\begin{array}{l}\text { Organisation/ } \\
\text { Institution }\end{array}$ & Report or database title & $\begin{array}{l}\text { Number } \\
\text { of } \\
\text { indicators }\end{array}$ & URL for website or PDF & Reference \\
\hline Regional & $\begin{array}{l}\text { Observatorio } \\
\text { Valenciano de la Salud }\end{array}$ & $\begin{array}{l}\text { Desigualdades en Salud en la } \\
\text { Comunidad Valenciana }\end{array}$ & 26 & $\begin{array}{l}\text { https://www.sp.san.gva.es/DgspPortal/ } \\
\text { docs/20180301_Desigualdades_Salud_Ovs2 } \\
\text { 018.pdf }\end{array}$ & [43] \\
\hline Regional & $\begin{array}{l}\text { Ajuntament de } \\
\text { Barcelona }\end{array}$ & $\begin{array}{l}\text { Desigualtats en salut, respostes a nivell } \\
\text { local: Polítiques per reduir les desigualtats } \\
\text { en salut a la ciutat de Barcelona }\end{array}$ & 22 & $\begin{array}{l}\text { http://www.consorci.org/media/upload/ } \\
\text { arxius/coneixement/salut-publica/2017/ } \\
\text { D_\%20Malmusi_Desigualtats_28-09-2017.pdf }\end{array}$ & [42] \\
\hline Regional & $\begin{array}{l}\text { Escuela Andaluza de } \\
\text { Salud Pública }\end{array}$ & $\begin{array}{l}\text { Guía de indicadores para medir las } \\
\text { desigualdades de género en salud y sus } \\
\text { determinantes }\end{array}$ & 55 & $\begin{array}{l}\text { https://www.easp.es/project/guia-de- } \\
\text { indicadores-para-medir-las-desigualdades- } \\
\text { de-genero-en-salud-y-sus-determinantes/ }\end{array}$ & [41] \\
\hline
\end{tabular}

indicators they included. The names of the indicators in the spreadsheets were those given in the original reports or their metadata information.

\section{Results}

In total, 21 reports, projects, and databases were identified and classified into three categories: 1. international [8], 2. national [10], and 3. regional [3]. In the first category, international, all the projects selected were carried out or funded by the European Commission [23-27], the WHO [28, 29] or the World Bank [30]. In the following category, national, studies were conducted by health agencies or governments of countries such as Andorra [31], Australia [32], Canada [33, 34], England [35, 36], Scotland [37], Slovenia [38], Spain [39] or Portugal [40]. In the last category, regional, some reports published by Spanish regions were included (Andalucía [41], Barcelona [42], Valencia [43]). A total of 691 health indicators were identified (Table 1).

Following an iterative process of evaluation, we identified a core set of 120 candidate topics, of which 34 were finally selected (Fig. 1). Table 2 describes a complete list of 34 topics with the corresponding definition of each topic. The ten most commonly used were: "Life expectancy", "Infant mortality", "Obesity and overweight

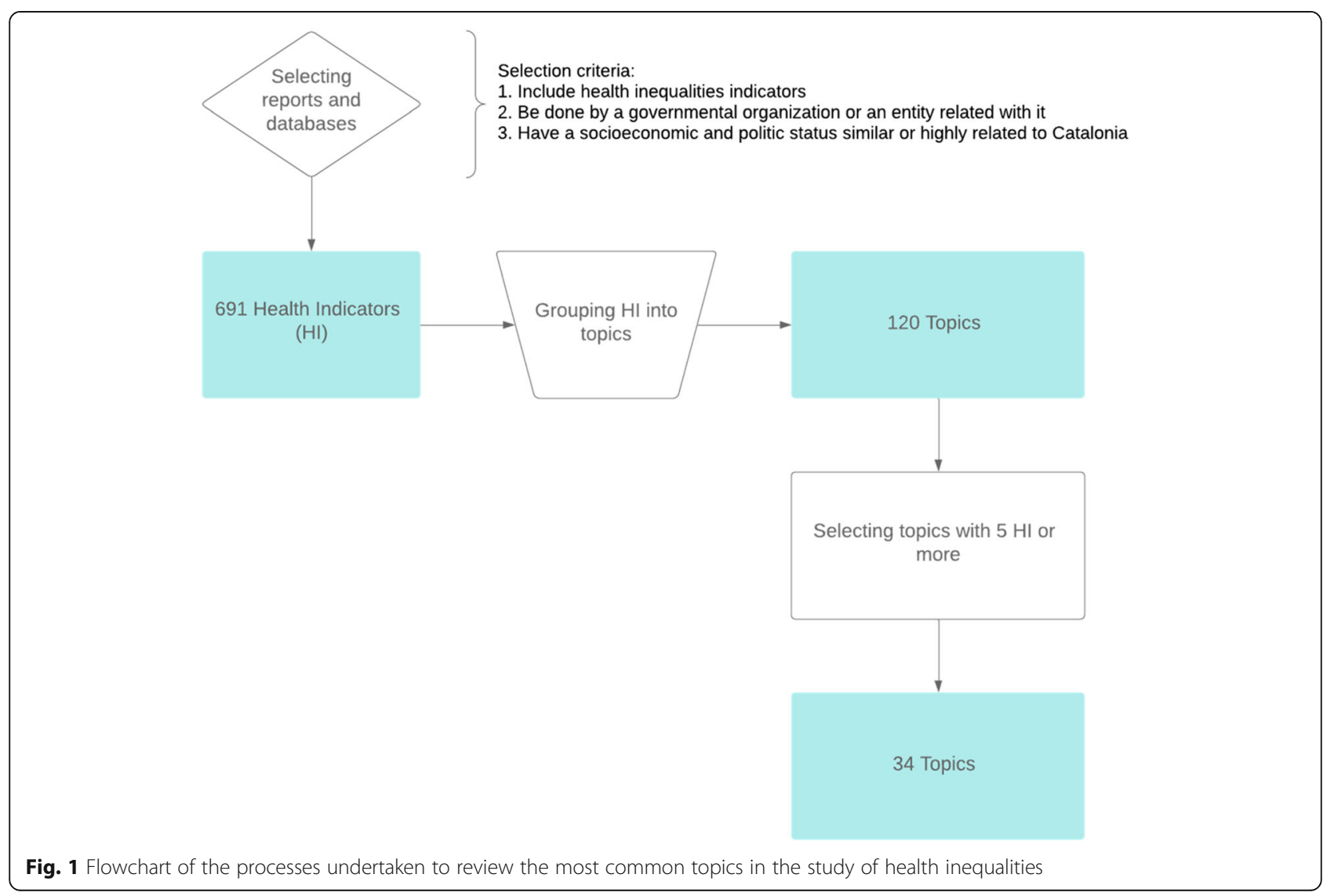


Table 2 List of topics ranked by the number of health indicators grouped within

\begin{tabular}{|c|c|c|}
\hline Topic & Description of measured topics & Reference \\
\hline Life expectancy & Time that a concrete population is expected to live. & {$[23-30,33-39,41-43]$} \\
\hline Infant mortality & Death of young children under the age of 1 in a population. & {$[24-30,33,34,36,38-42]$} \\
\hline Obesity and overweight (BMI) & $\begin{array}{l}\text { Measurement of people having more body fat than is optimally healthy, } \\
\text { to an extent that it may have a negative effect on health. }\end{array}$ & $\begin{array}{l}{[22,24,25,27,29-33,36,38} \\
42,43]\end{array}$ \\
\hline Mortality rate & $\begin{array}{l}\text { Measurement of the number of deaths in a particular population, scaled } \\
\text { to the size of that population, per unit of time. }\end{array}$ & $\begin{array}{l}{[25-27,29,30,34,37,38,40-} \\
43]\end{array}$ \\
\hline $\begin{array}{l}\text { Regular smokers/ tobacco } \\
\text { consumption }\end{array}$ & $\begin{array}{l}\text { Measurement of the number of people consuming tobacco (smoking) } \\
\text { in a population. }\end{array}$ & $\begin{array}{l}{[23-25,27,29,31-34,38,42} \\
43]\end{array}$ \\
\hline Self-perceived health & $\begin{array}{l}\text { Measurement of the expression of subjective assessment by the } \\
\text { respondent of his/her health. }\end{array}$ & $\begin{array}{l}{[23-26,31,32,34,36-38,42} \\
43]\end{array}$ \\
\hline Unemployment & $\begin{array}{l}\text { Measurement of people above a specified age that are not in paid } \\
\text { employment or self-employment and are currently available for work } \\
\text { during the reference period. }\end{array}$ & $\begin{array}{l}{[24,25,27,28,30,34,36,38} \\
39,41,42]\end{array}$ \\
\hline Mental well-being & Level of psychological well-being or an absence of mental illness. & {$[24,29,33,34,36-39,41-43]$} \\
\hline Cardiovascular disease/ hypertension & $\begin{array}{l}\text { Measurement of the number of people affected by cardiovascular } \\
\text { disease (CVD) or hypertension in a population. }\end{array}$ & $\begin{array}{l}{[24,27,29,32,34,36-38,41} \\
43]\end{array}$ \\
\hline $\begin{array}{l}\text { Socioeconomic status (SES)/ material } \\
\text { deprivation }\end{array}$ & $\begin{array}{l}\text { Measurement of the social standing or class of individuals in a population, } \\
\text { as well as the state of economic strain and durables. }\end{array}$ & {$[24,25,28,33-35,38,39,42]$} \\
\hline Diabetes/ insulin resistance & $\begin{array}{l}\text { Measurement of people affected by diabetes (a chronic, metabolic disease } \\
\text { characterised by elevated levels of blood glucose) or insulin resistance in } \\
\text { a population. }\end{array}$ & {$[24,25,29,30,32-34,38,41]$} \\
\hline Physical activity & $\begin{array}{l}\text { Measurement of physical activity (any bodily movement produced by } \\
\text { skeletal muscles that requires energy expenditure) in a population. }\end{array}$ & {$[24,29,31,32,34,38,39,42]$} \\
\hline Cancer & $\begin{array}{l}\text { Measurement of people affected by cancer (group of diseases that can start } \\
\text { in almost any organ or tissue of the body when abnormal cells grow } \\
\text { uncontrollably, go beyond their usual boundaries to invade adjoining parts } \\
\text { of the body and/or spread to other organs) in a population. }\end{array}$ & {$[24,25,27,33,34,36,37,43]$} \\
\hline HIV & $\begin{array}{l}\text { Measurement of people affected by HIV (an infection that attacks the body's } \\
\text { immune system, specifically the white blood cells, called CD4 cells) in a } \\
\text { population. }\end{array}$ & {$[23,24,27,29,30,34,40,41]$} \\
\hline $\begin{array}{l}\text { Long-term limitations/ chronic } \\
\text { illnesses }\end{array}$ & $\begin{array}{l}\text { Measurement of people affected by diseases or conditions that are persistent } \\
\text { or long-lasting. }\end{array}$ & {$[23-26,31,34,36,37]$} \\
\hline Tuberculosis & $\begin{array}{l}\text { Measurement of people with health issues caused by the infection of the } \\
\text { bacteria Mycobacterium tuberculosis in a population. }\end{array}$ & {$[23,29,30,33,34,40,42,43]$} \\
\hline Hazardous alcohol consumption & Measurement of hazardous alcohol consumption in a population. & {$[24,29,32-34,37,38]$} \\
\hline Low birthweight & Measurement of birth weights of infants of $2499 \mathrm{~g}$ or less in a population. & {$[27,29,34,37,38,41,42]$} \\
\hline $\begin{array}{l}\text { Perinatal, neonatal and stillbirths } \\
\text { mortality }\end{array}$ & Measurement of foetus or neonate deaths in a population. & {$[24,27,29,30,36,38,43]$} \\
\hline General practitioner (GP) utilisation & $\begin{array}{l}\text { Measurement of the utilisation of general practitioners (medical doctors) in } \\
\text { a population. }\end{array}$ & {$[24,26,31,32,34,36,39]$} \\
\hline Suicide/self-harm & $\begin{array}{l}\text { Measurement of the number of intentionally self-caused deaths and/or } \\
\text { other intentional self-harm injuries in a population. }\end{array}$ & {$[25,29,33,34,36,38,43]$} \\
\hline Healthcare resources & $\begin{array}{l}\text { Measurement of resources such as materials, personnel or facilities that can } \\
\text { be used to provide healthcare. }\end{array}$ & {$[24,27,30,38-40,43]$} \\
\hline Alcohol consumption & $\begin{array}{l}\text { Measurement of people consuming alcohol (a toxic and psychoactive } \\
\text { substance with dependence-producing properties) regularly in a population. }\end{array}$ & {$[24,25,31,32,37,38]$} \\
\hline $\begin{array}{l}\text { Road traffic accidents (injuries and } \\
\text { deaths) }\end{array}$ & $\begin{array}{l}\text { Measurement of deaths and injuries due to road traffic accidents (crashes) } \\
\text { in a population. }\end{array}$ & {$[23,24,27,29,30,38]$} \\
\hline $\begin{array}{l}\text { Food consumption (vegetables, fruit, } \\
\text { salt) }\end{array}$ & Measurement of people ingesting solid foods in a population. & {$[24,29,32,34,38,39]$} \\
\hline Primary studies/ illiteracy & $\begin{array}{l}\text { Measurement of people with primary studies (first stage of } \\
\text { formal education) or illiterate (not able to read) in a population. }\end{array}$ & {$[24,28,32,35,39,42]$} \\
\hline Child well-being & Indicators to measure the general health, proper growth, and well-being & {$[31,33,35,39-41]$} \\
\hline
\end{tabular}


Table $\mathbf{2}$ List of topics ranked by the number of health indicators grouped within (Continued)

\begin{tabular}{|c|c|c|}
\hline Topic & Description of measured topics & Reference \\
\hline Respiratory disease & $\begin{array}{l}\text { Measurement of people affected by a disease affecting the organs and } \\
\text { tissues that make gas exchange in a population. }\end{array}$ & {$[24,29,32,36,38,41]$,} \\
\hline Work-related health risks & $\begin{array}{l}\text { Measurements of risks and/or diseases as a result of an exposure to risk } \\
\text { factors from work activity in a population. }\end{array}$ & {$[23,24,29,36,39,43]$} \\
\hline Dental care/ oral health & $\begin{array}{l}\text { Measurement of people with oral diseases or provided with dental health } \\
\text { services in a population. }\end{array}$ & {$[26,32-34,36,38]$} \\
\hline Policy and legislation & Indicators measuring policy-making initiatives. & {$[24,28,29,36,39,40]$} \\
\hline Perceived mental health & $\begin{array}{l}\text { Measurement of the expression of subjective assessment by the respondent } \\
\text { of his/her mental health and/or psychological well-being. }\end{array}$ & {$[24,30,33,34,36]$} \\
\hline Unintentional injuries & $\begin{array}{l}\text { Measurement of people affected by any injury that is not caused on } \\
\text { purpose or with intention to harm in a population. }\end{array}$ & {$[24,33,36,38,41]$} \\
\hline Pregnancy care/ breastfeeding & $\begin{array}{l}\text { Indicators measuring the care provided during pregnancy or other } \\
\text { pregnancy-related issues, such as breastfeeding, in a population. }\end{array}$ & {$[24,32,34,39,41]$} \\
\hline Hip fractures and surgical procedures & $\begin{array}{l}\text { Measurement of the amount of surgical procedures and/or relevant fractures } \\
\text { that will likely require surgical procedures (i.e. hip fractures) in a population. }\end{array}$ & {$[24,30,36,41,43]$} \\
\hline
\end{tabular}

(BMI)", "Mortality rate", "Regular smokers/tobacco consumption", "Self-perceived health", "Unemployment", "Mental well-being", "Cardiovascular disease/hypertension", "Socioeconomic status (SES)/material deprivation". However, some topics that ranked below these were closely related with some of the most common topics; for example, "Perinatal, neonatal and stillbirths mortality" might be considered as a subtype of "Infant mortality"; and "Perceived mental health" is similar to both "Mental well-being" and "Self-perceived health". Furthermore, some indicators may represent antithetically the same area of knowledge; that is the case for the indicators in the topic "Long-term limitations/chronic illnesses" and the indicator "Healthy Life Years (HLY)" [within the topic "Life expectancy"], where the former (long-term limitations or chronic illnesses) is used to determine the latter (the end of a healthy life condition). Nevertheless, the metadata of the health indicators within each topic was highly homogeneous: they all had similar definitions and methodology.

In general, the indicators within each topic were very similar. In fact, often the differences among them were related to the different stratifiers (such as sex, age or region) used for their calculation. For example, in the first topic "Life expectancy", indicators have different variations: "Life expectancy at birth" [23-25, 27-29, 32, 33, 37, 4042], "Life expectancy at birth by sex" [22, 24-27, 33, 34], "Life expectancy at a certain age" $[25,33,35,40]$, "Life expectancy by educational attainment level" [25], and "Life expectancy at birth by socioeconomic status" [25]. Complex measures of inequality, such as "Slope index of inequality (SII) for male and female life expectancy" [34] may be considered another (more advanced) variation.

Furthermore, in the case of a health outcomes or diagnostics (such as mortality or cancer) the concrete disease or cause may also play an important role in the heterogeneity found among the health indicators. Indicators are focused on different aspects, such as prevalence and incidence, mortality, preventive measures, or treatments. For example, for the topic "HIV": "HIV incidence" [23, 26, 28, 33, 40], "Prevalence of HIV, male/female, by ages" [29, 39] and "AIDS-related mortality rate" $[28,39]$ are the most common, yet "Antiretroviral therapy (ART) coverage" [28] and "HIV test results for TB patients (positive results)" [28] can also be relevant.

The results of the study show that the most common topics are related to:

- Mortality/life expectancy: "Life expectancy" [44, 45], "Infant mortality" [46] or "Mortality rate" [47] are widely used to study health inequalities.

- Incidence/mortality rates of specific diseases: "Cardiovascular disease/hypertension", "Cancer (incidence or mortality)" [48], "Diabetes/insulin resistance" [49], "HIV" [50], "Tuberculosis (TB)" [51] or "Respiratory diseases".

- Social determinants of health [52]:

- "Living and working conditions" where this could be studied at an individual level, was highly ranked: "Unemployment" [53] and "Primary studies/illiteracy". Otherwise, these indicators were at the bottom of the list.

- This was similar for "Individual lifestyle factors and social and community networks" topics, which can also be studied at an individual level: "Obesity and overweight (BMI)" [54, 55], "Regular smokers/ tobacco consumption" [56], "Alcohol consumption" [57], "Hazardous alcohol consumption", "Physical activity" [58], and "Food consumption (vegetables, fruit, salt)".

- Socioeconomic level: "Socioeconomic status (SES)/material deprivation" [59, 60]. 
- Healthcare system: "Healthcare resources" and "Policy and Legislation".

\section{Discussion}

\section{Main results of the study}

The results of the study showed that the most common topics were related to mortality/life expectancy, incidence/mortality rates of specific diseases (i.e., TB or HIV), and social determinants of health, such as living and working conditions, and individual lifestyle factors and social and community networks, according to Dahlgren and Whitehead's model of the social determinants of health [52]. The indicators that can be studied at an individual level tended to be highly ranked, in comparison to those that are studied at different levels (such as hospital or region), which tended to be at the bottom. Many methodological differences between indicators were due to stratifiers in their calculation.

\section{Study selection criteria}

To include health inequalities indicators was a fundamental requirement for any report in order to be included in the review. Hence, although some reports provided in-depth insights about tackling health inequalities (i.e., [21, 61]) they were not selected due to lack of health indicators monitoring.

In addition, to be carried out by a governmental or a government-related organisation was also an important requirement, as many academic and/or private institutions carry out studies and reviews of health inequalities, but their policy-making influence is limited. Their reports tend to be focused on concrete knowledge fields, such as gender influence [62], the effects of economic crises [63], or access to healthcare [64]; which are also relevant for the study of health inequalities but whose authorship does not fit the selection criteria, as the main interest of this paper is identifying the health inequalities indicators used by health agencies or similar government-related entities. The reports not produced by this kind of organisation were rejected.

Lastly, to have a socioeconomic and politic status similar or highly related to Catalonia criteria was intended to exclude reports whose health indicators were adapted to least developed/developing countries where, for example, access to treatments of diarrhea for infants may still be an issue [65]. Hence, some reports were discarded due to significant differences in the socioeconomic profile of the countries they are studying in comparison to Catalonia or Spain.

These criteria were applied to all the reports and studies found after an extensive search. The addition of country/region names in the search responded to the need of knowing how particular regions of interest were dealing with health inequalities. Interest in regions was mainly based on previous knowledge of concrete public health organizations studying those regions, as well as interest in looking for other organizations in charge of tackling health inequalities in regions similar to Catalonia. Nevertheless, as in any review, it is not possible to ensure that absolutely all the reports suitable for this study were found during the search, nor that they were selected after applying the selection criteria.

\section{Grouping health indicators into topics}

As stated above, the most frequent health indicators were grouped into topics according to the health domain they were measuring (with each indicator related to only one topic). For example, although "Percentage of 15year-olds who were overweight in 2009-10, EU Member States by sex" [25] and "Obesity rate by body mass index (BMI) (sdg_02_10)" [23, 66] are different indicators per se, they are both intended to measure the same health issue and, hence, were grouped under the same topic "Obesity and overweight (BMI)" under the indicator name "Obesity and/or overweight (total, by sex, age, or educational level)".

Most of the selected health indicators were taken from the official statistics of different countries or international organisations, whose development and methodology has been closely consolidated over many years and respond to international standards. In addition, most of these indicators are related to relevant knowledge areas for the study of health inequalities, such as lifestyle habits, deprivation, and mortality.

To prioritise the most relevant topics, all the groups with less than five health indicators were deleted. This meant that, unfortunately, interesting topics such as the "Years of potential life lost" [34, 36, 42], "Unmet health needs" [23, 26, 39] and "Passive smokers" $[33,34]$ were not taken into consideration. Nevertheless, this selection does not imply per se a periodic monitoring of the selected health indicators, as specific topics not present in this list may be studied according to ultimate needs.

\section{Relevance of the most common topics}

All the topics aim to measure and study the relation between determinants of health and health outcomes. Interestingly, three of the top five topics in the list (see Table 2) are related to mortality: life expectancy, infant mortality, and mortality rate. Life expectancy at birth is an indicator of mortality conditions and, by proxy, of health conditions [44]. Hence, life 
expectancy as well as other mortality-related topics are widely used in the study of health inequalities.

Living and working conditions, such as BMI or smoking, are also key factors in the study of health inequalities as both share a strong socioeconomic gradient [54, 56]. Therefore, as may be expected, they appeared among the top 10 positions in the list of topics (see Table 2). According to our review, the most common way to measure socioeconomic status is to analyse the unemployment rates and material deprivation level of the population.

In Spain, some regions use less common health indicators for studying health inequalities that may be interesting for particular knowledge areas. For example, the Valencian Observatory of Health uses the "Caregiver profile", which they report to be mostly women, without primary studies, 57-years-old on average, and reporting bad self-perceived health. In addition, they also use "Reasons why contraceptive methods are not used by age and nationality of women" as well as a "Sexual-health information resources (school, parents, friends, etc.)", which may help to understand possible sexual health inequalities [43]. In the Andalusian School of Public Health, the indicator "Psychosis and mental illnesses due to drugs or alcohol abuse" may be helpful to estimate various negative health outcomes of alcohol and substance abuse that the healthcare system will need to address [41]. Even so, more than a half of topics in Table 2 appear in their reports.

As may be expected, the health indicators used in other reports produced by the Catalan Health System Observatory, such as the "Community Health Indicators", match the implicit measurement concept behind many of the topics: obesity and overweight, mortality by age (including infant), self-perceived health, and population with primary studies are some of them [67].

\section{Health indicators}

As can be seen in Table 3, health indicators were combined within each topic if stratifiers such as population sex, age, or region were the only difference in their calculation methodologies. Some indicators were also merged if they were formerly different in the way they expressed the same data (i.e., raw number, rate per 1000 or 100,000).

The health indicators within each topic often cover a different aspect relevant to health inequalities. For example, in the topic "Tuberculosis" [23, 29, 33, 34, $40,42,43]$ indicators about incidence, prevalence, or mortality can be observed. In addition, health indicators about treatment coverage or vaccination are also included in this topic. Overall, in most topics, indicators try to measure every relevant (and measurable) aspect of the topic.

Common stratifiers are sex, age, and studied region, something that is coherent with the determinants of health perspective and the focus on inequalities. However, the stratifiers found are highly heterogeneous and may also include socioeconomic status, educational level, or nationality/country of origin, among many others.

\section{Research fitted to monitor health inequalities}

This comprehensive review was carried out to help accomplish the first step in the process for tackling and monitoring health inequalities: selecting highimpact issues and health indicators $[19,20]$. The next steps in the analysis will be to carefully take into account stratifiers such as area of residence, gender, age, and nationality. Lastly, after the identification of key health inequalities, decision-making stakeholders will need to play a role during the last steps: determining priorities of action and implementing changes. The time variable will play a key role in the monitoring, as it will indicate the possible health consequences of policy-making decisions $[19,20]$.

\section{Conclusions}

Reviewing the most common health indicators and topics used in the study of health inequalities may help research teams in different ways. First, having an overview of what is being done by their neighbouring countries or regions may highlight issues that should not be missed when selecting relevant health topics to study. Second, even if some topics might not ultimately be chosen as a priority of action, having a complete list of key issues will provide an overview of what is relevant in the study of health inequalities, as well as some interesting insights. Lastly, knowing what other research institutions are working on will promote potential collaborations between organizations, creating synergies and bonds that may lead to better understanding and monitoring of health inequalities.

At a regional level, these results are highly valuable for the first stages of health inequalities monitoring cycles in Catalonia. This study provided the basis for choosing health topics to study as well as helped gain insights about which indicators should be used. In addition, regions with similar socioeconomic status and goals in tackling health inequalities may benefit from this research. Similarly, at a national and international level these results may help organizations shift the focus towards undermined health inequalities 
Table 3 List of indicators by topic

\begin{tabular}{|c|c|c|}
\hline Topics & Indicators & Reference \\
\hline \multirow[t]{5}{*}{ Life expectancy } & $\begin{array}{l}\text { Life expectancy at birth or at certain age (total, by sex, educational level } \\
\text { and/or socioeconomic status) }\end{array}$ & {$[23-30,33-36,38,41-43]$} \\
\hline & Health-adjusted life expectancy & {$[33,34]$} \\
\hline & $\begin{array}{l}\text { Inequality in life expectancy, slope index of inequality (SII) for male and } \\
\text { female life expectancy }\end{array}$ & {$[35,39]$} \\
\hline & Healthy life years (total, by sex, region and/or socioeconomic status) & {$[25,26,36,37,39,43]$} \\
\hline & Slope index of inequality for male and female disability-free life expectancy & {$[35]$} \\
\hline \multirow[t]{4}{*}{ Infant mortality } & $\begin{array}{l}\text { Infant mortality (total, by sex, by socioeconomic status, deprivation or } \\
\text { disposable family income) }\end{array}$ & {$[24-30,33,34,36,38,40-42]$} \\
\hline & Infant mortality of newborns weighting at least $500 \mathrm{~g}$ & {$[34]$} \\
\hline & Inequality in infant mortality & {$[39]$} \\
\hline & $\begin{array}{l}\text { Highest and lowest infant mortality rates per } 1000 \text { live births and measures } \\
\text { of inequality between EU Member States, 2000-2010 }\end{array}$ & {$[25]$} \\
\hline \multirow[t]{2}{*}{ Obesity and overweight (BMI) } & Obesity and/or overweight (total, by sex, age, or educational level) & $\begin{array}{l}{[22,24,25,27,29-33,36,38,} \\
42,43]\end{array}$ \\
\hline & Body mass index & {$[24]$} \\
\hline \multirow[t]{3}{*}{ Mortality rate } & All-cause mortality (total, by sex, age, or region) & {$[25,27,29,34,37,38,41-43]$} \\
\hline & Death rates by cause of death & {$[26,29,40,42]$} \\
\hline & $\%$ completeness of death registration with cause-of-death information & {$[30]$} \\
\hline \multirow[t]{3}{*}{ Regular smokers /tobacco consumption } & $\begin{array}{l}\text { Smoking/tobacco consumption (total, by frequency of consumption, age, } \\
\text { sex, employment and occupational status and/or by difficulties } \\
\text { experienced in paying bills) }\end{array}$ & {$[23-25,27,29,31-34,38,42]$} \\
\hline & Tobacco and alcohol consumption & {$[43]$} \\
\hline & Pregnant women smoking & {$[24]$} \\
\hline \multirow[t]{2}{*}{ Self-perceived health } & Self-perceived health (total, by age and/or sex) & $\begin{array}{l}{[23-26,31,32,34,37,38,42,} \\
43]\end{array}$ \\
\hline & $\begin{array}{l}\text { Total health gain as assessed by patients for elective procedures: physical } \\
\text { health related procedures/psychological therapies }\end{array}$ & [36] \\
\hline \multirow[t]{6}{*}{ Unemployment } & Unemployment (total, by duration/long-term) & {$[24,25,27,28,30,38,42]$} \\
\hline & $\begin{array}{l}\text { Employment of people with long-term conditions/mental illness/ } \\
\text { disabilities }\end{array}$ & {$[36,41]$} \\
\hline & Eligibility for employment insurance (aged 15-69) & [34] \\
\hline & Age dependency ratio (\% working-age population) & {$[30]$} \\
\hline & Population living in jobless households & {$[39]$} \\
\hline & Employment gap & {$[39]$} \\
\hline \multirow[t]{8}{*}{ Mental well-being } & Risk of psychological suffering & {$[42]$} \\
\hline & $\begin{array}{l}\text { Health-related quality of life for people with mental illness } \\
\text { (eventual or recovery) }\end{array}$ & {$[36]$} \\
\hline & Psychological well-being or discomfort (by age, by using GHQ-12) & {$[24,37,43]$} \\
\hline & Mental disorders or illness (ICD9MC: 290-319 / including addictions) & {$[39,41]$} \\
\hline & $\begin{array}{l}\text { Morbidity: neurotic, personality, and other non-psychotic mental disorders } \\
\text { (except drugs or alcohol) (ICD9MC: 300-302, 306-319) }\end{array}$ & {$[41]$} \\
\hline & Depression (mental health) & {$[38]$} \\
\hline & Mental illness hospitalisation rate (total, by age) & {$[33,34]$} \\
\hline & Coverage of services for severe mental health disorders & {$[29]$} \\
\hline \multirow[t]{3}{*}{ Cardiovascular disease/ hypertension } & $\begin{array}{l}\text { Mortality due to cardiovascular causes, including heart diseases } \\
\text { (total, by sex and/or age) }\end{array}$ & {$[27,34,36,37,43]$} \\
\hline & Arterial hypertension & {$[32,38,41]$} \\
\hline & Blood pressure & {$[24,29]$} \\
\hline
\end{tabular}


Table 3 List of indicators by topic (Continued)

\begin{tabular}{|c|c|c|}
\hline Topics & Indicators & Reference \\
\hline & Proportion of stroke patients reporting an improvement in activity & {$[36]$} \\
\hline & $\begin{array}{l}\text { Cardiovascular and heart diseases (including heart attacks, angina pectoris, } \\
\text { and heart failure) }\end{array}$ & {$[38]$} \\
\hline & First ever hospital admission for heart attack (aged under 75 years) & {$[37]$} \\
\hline & 30-day in-hospital case-fatality AMI and stroke & {$[24]$} \\
\hline \multirow{11}{*}{$\begin{array}{l}\text { Socioeconomic status (SES)/ material } \\
\text { deprivation }\end{array}$} & Working poor & {$[33,34,39]$} \\
\hline & Disposable family income/family SES & {$[39,42]$} \\
\hline & Income tax base & {$[38]$} \\
\hline & People in households in receipt of means-tested benefits & {$[35]$} \\
\hline & $\begin{array}{l}\text { Slope index of inequality for people in households in receipt of } \\
\text { means-tested benefits }\end{array}$ & {$[35]$} \\
\hline & $\begin{array}{l}\% \text { at risk of poverty - with less than } 60 \% \text { of the median income } / \% \text { at } \\
\text { persistent risk of poverty (by intensity of poverty) }\end{array}$ & [39] \\
\hline & $\%$ who own a house and car & {$[39]$} \\
\hline & $\%$ areas with $>20 \%$ population poor & [39] \\
\hline & $\begin{array}{l}\text { Age-standardised percentage of people aged } 25 \text { and over by severity of } \\
\text { material deprivation }\end{array}$ & {$[25]$} \\
\hline & $\begin{array}{l}\text { SIII Income/SII Deprivation (by perceived health)/inequality relative index/ } \\
\text { Gini coefficient (income distribution)/salary gap/income inequality } \\
\text { (S80/S20) within and across local areas }\end{array}$ & {$[25,28,39]$} \\
\hline & Population below poverty line and income inequality & {$[24]$} \\
\hline \multirow[t]{4}{*}{ Diabetes / Insulin resistance } & Age-standardised prevalence rate of anti-diabetic drug recipients & {$[38]$} \\
\hline & Diabetes (excluding gestational) (by region, age) & {$[25,30,32-34,41]$} \\
\hline & Raised blood glucose/diabetes among adults & {$[29]$} \\
\hline & Diabetes control & {$[24]$} \\
\hline \multirow[t]{4}{*}{ Physical activity } & $\begin{array}{l}\text { Physical activity, active or moderately active (total or during free time, by } \\
\text { sex and/or age) }\end{array}$ & {$[24,31,34,38]$} \\
\hline & Sedentarism/insufficient physical activity & {$[29,32,42]$} \\
\hline & $\%$ children by the number of hours of physical activity during a week & {$[38]$} \\
\hline & Little social or recreational activity & {$[39]$} \\
\hline \multirow[t]{5}{*}{ Cancer } & Cancer mortality (total, by sex, age) & {$[27,36,37]$} \\
\hline & Cancer incidence (total, by age) & {$[25,34,37]$} \\
\hline & Lung cancer incidence or mortality & {$[33,34,43]$} \\
\hline & $\begin{array}{l}\text { Survival rates cancer ( } 1-5 \text { years from all cancers/diagnosed at stages } 1 \text { and } \\
\text { 2) }\end{array}$ & {$[24,36]$} \\
\hline & Colorectal cancer screening, past 5 years (aged 50-74) & {$[34]$} \\
\hline \multirow[t]{7}{*}{ HIV } & HIV incidence / prevalence (total, by sex, age) & {$[24,27,29,30,34,40,41]$} \\
\hline & AIDS-related mortality rate & {$[29,40]$} \\
\hline & People living with HIV who know their status & {$[29]$} \\
\hline & Antiretroviral therapy coverage & {$[29]$} \\
\hline & Prevention of mother-to-child transmission & {$[29]$} \\
\hline & HIV test results for TB patients (positive results) & {$[29]$} \\
\hline & Death rate due to TB, HIV, and hepatitis by sex & {$[23]$} \\
\hline \multirow[t]{4}{*}{ Long-term limitations/ chronic illnesses } & Health-related quality of life for people with long-term conditions & {$[36]$} \\
\hline & Long-term/chronic conditions, limitations, or illness (total, by age, sex) & {$[24,25,31,34,37]$} \\
\hline & Self-reported chronic morbidity or limitations in daily activities & {$[24,26]$} \\
\hline & Physical and sensory functional limitations & {$[24]$} \\
\hline
\end{tabular}


Table 3 List of indicators by topic (Continued)

\begin{tabular}{|c|c|c|}
\hline Topics & Indicators & Reference \\
\hline & Death rate due to chronic diseases by sex & {$[23]$} \\
\hline \multirow[t]{5}{*}{ Tuberculosis } & Incidence/prevalence of TB (by country of origin, nationality, age, and sex) & {$[29,30,33,34,40,42,43]$} \\
\hline & Evolution of anti-TB vaccination (BCG) & {$[40]$} \\
\hline & TB notification rate & [29] \\
\hline & $\begin{array}{l}\text { Coverage for TB treatment/drug susceptibility testing (for active, latent } \\
\text { infection or drug-resistant) }\end{array}$ & [29] \\
\hline & Death rate due to TB, HIV, and hepatitis by sex & {$[23]$} \\
\hline \multirow[t]{4}{*}{ Hazardous alcohol consumption } & Hazardous alcohol consumption/heavy drinking (total, by age) & {$[24,33,34,38]$} \\
\hline & Alcohol-related deaths (aged 45-74 years) & {$[37]$} \\
\hline & High-risk alcohol consumption & {$[32]$} \\
\hline & $\begin{array}{l}\text { Harmful use of alcohol, defined according to the national context as } \\
\text { alcohol per capita consumption (aged } 15 \text { years and older) within a } \\
\text { calendar year in litres of pure alcohol }\end{array}$ & [29] \\
\hline \multirow[t]{4}{*}{ Low birthweight } & Low birthweight & {$[27,29,34,37,38,42]$} \\
\hline & Preterm delivery & {$[29,38]$} \\
\hline & $\begin{array}{l}\text { Hospital discharges due to delayed intrauterine growth, foetal malnutrition, } \\
\text { shortened pregnancy and low birth weight, caesarean sections, and low } \\
\text { birth weight infants (by province) }\end{array}$ & {$[41]$} \\
\hline & Small for gestational age & {$[34]$} \\
\hline \multirow{6}{*}{$\begin{array}{l}\text { Perinatal, neonatal, and stillbirths/foetal } \\
\text { mortality }\end{array}$} & Perinatal mortality & {$[24,27,43]$} \\
\hline & Neonatal mortality rate & {$[29,30,36]$} \\
\hline & Under-5 mortality rate & {$[29,30]$} \\
\hline & Stillbirth mortality & {$[29,36]$} \\
\hline & Foetal mortality by nationality & {$[43]$} \\
\hline & Stillbirths, perinatal mortality, and infant mortality & [38] \\
\hline \multirow[t]{4}{*}{ General practitioner (GP) utilisation } & $\begin{array}{l}\text { Health professionals (including doctor/GP/specialist) consultations } \\
\text { (by time period) }\end{array}$ & {$[31,32,34]$} \\
\hline & Care utilisation (including GP) & {$[24,26]$} \\
\hline & Experience of GP services/Out of Hours service & [36] \\
\hline & $\%$ without a GP & [39] \\
\hline \multirow[t]{3}{*}{ Suicide/self-harm } & Suicide mortality & {$[25,29,33,34,38]$} \\
\hline & $\begin{array}{l}\text { Suicide and mortality from injury of undetermined intent among people } \\
\text { with recent contact from NHS }\end{array}$ & {$[36]$} \\
\hline & Suicides and self-injuries & [43] \\
\hline \multirow[t]{6}{*}{ Healthcare resources } & Hospital beds & {$[24,27,30]$} \\
\hline & Health facilities & {$[40]$} \\
\hline & $\%$ areas understaffed in health \& education & [39] \\
\hline & Physicians employed (total or rate, by region) & {$[24,27,38,40]$} \\
\hline & Specialist surgical workforce (per 100,000 population) & [30] \\
\hline & Nurses employed including/excluding midwives (total and rate) & {$[24,27,40]$} \\
\hline \multirow[t]{4}{*}{ Alcohol consumption } & Alcohol consumption (total, by sex) & {$[24,31,38]$} \\
\hline & Alcohol first hospital admissions (aged under 75 years) & [37] \\
\hline & Alcohol risk & [32] \\
\hline & Patterns of alcohol consumption & [25] \\
\hline \multirow{3}{*}{$\begin{array}{l}\text { Road traffic accidents (injuries and } \\
\text { deaths) }\end{array}$} & Mortality caused by road traffic injury (per 100,000 people) & {$[29,30]$} \\
\hline & Healthy life years lost by traffic accidents and falls & [38] \\
\hline & Road injuries and deaths (register-based and self-reported) & {$[23,24,27]$} \\
\hline
\end{tabular}


Table 3 List of indicators by topic (Continued)

\begin{tabular}{|c|c|c|}
\hline Topics & Indicators & Reference \\
\hline \multirow{3}{*}{$\begin{array}{l}\text { Food consumption (vegetables, fruit, } \\
\text { salt) }\end{array}$} & Fruit/vegetable consumption (total, by times a day, by age) & {$[24,34,38]$} \\
\hline & Salt intake & {$[29,32]$} \\
\hline & Low access to healthy food & [39] \\
\hline \multirow[t]{5}{*}{ Primary studies/illiteracy } & Population by education (including early school leavers) & {$[24,28,39,42]$} \\
\hline & Young people who are not in education, employment or training & {$[35]$} \\
\hline & Days away from study or work & {$[32]$} \\
\hline & Results in math and literacy or years of education & [39] \\
\hline & $\%$ illiterate or does not know the language well & [39] \\
\hline \multirow[t]{4}{*}{ Child well-being } & Hospital discharges in girls and boys by age & {$[41]$} \\
\hline & Children well-being/achieving a good level of development at age 5 & {$[35,39]$} \\
\hline & Early childhood development & [33] \\
\hline & $\begin{array}{l}\text { Incidence of one of the } 17 \text { most common disorders in children, by sex } \\
\text { and age }\end{array}$ & {$[31]$} \\
\hline \multirow[t]{4}{*}{ Respiratory disease } & Mortality rate from respiratory disease (including COPD, total, by age) & {$[36,38]$} \\
\hline & COPD and associated diseases (ICD9MC: 490-496) & {$[24,41]$} \\
\hline & Bronchitis and acute bronchiolitis including emphysema (ICD9MC: 466) & {$[32,41]$} \\
\hline & Care-seeking for symptoms of pneumonia & [29] \\
\hline \multirow[t]{6}{*}{ Work-related health risks } & Health-related quality of life for carers & {$[36]$} \\
\hline & Occupational diseases & [43] \\
\hline & Work accidents & [39] \\
\hline & Health worker density and distribution & [29] \\
\hline & Work-related health risks & {$[24]$} \\
\hline & People killed in accidents at work & {$[23]$} \\
\hline \multirow[t]{7}{*}{ Dental care/ oral health } & Dental consultations & {$[26,32,34]$} \\
\hline & Tooth extractions in secondary care for children under 10 & {$[36]$} \\
\hline & $\begin{array}{l}\text { Dental care (regular brushing of teeth, regular visits to the dentist, proper } \\
\text { diet, and the use of protective agents) }\end{array}$ & {$[38]$} \\
\hline & Dental disease (caries and periodontal disease)] & {$[36,38]$} \\
\hline & Dental pain or discomfort, past month (aged 18+) & {$[34]$} \\
\hline & Inability to chew & {$[33,34]$} \\
\hline & Decay-missing-filled teeth index (aged 6-17) & {$[34]$} \\
\hline \multirow[t]{9}{*}{ Policy and legislation } & $\begin{array}{l}\text { A measure of the effectiveness of post-diagnostic care in sustaining } \\
\text { independence and improving quality of life }\end{array}$ & {$[36]$} \\
\hline & $\begin{array}{l}\text { New cases of International Health Regulations (IHR)-notifiable diseases and } \\
\text { other notifiable diseases }\end{array}$ & [29] \\
\hline & $\begin{array}{l}\text { Total net official development assistance to medical research and basic } \\
\text { health sectors prepared }\end{array}$ & [29] \\
\hline & $\begin{array}{l}\text { International health regulations capacity and health emergency } \\
\text { preparedness }\end{array}$ & {$[29]$} \\
\hline & Integrated programmes in settings, including workplace, schools, hospital & {$[24]$} \\
\hline & Expenditure on public health administrations & {$[40]$} \\
\hline & $\begin{array}{l}\text { Legislation, plans and funds to fight discrimination and structural health } \\
\text { inequalities }\end{array}$ & {$[28,39]$} \\
\hline & Prevention of HIV in key populations & [29] \\
\hline & Policies and practices on healthy lifestyles including nutrition & {$[24]$} \\
\hline \multirow[t]{2}{*}{ Perceived mental health } & Psychological distress (total or by place, by age) & {$[24,30,34]$} \\
\hline & Excess under 75 mortality rates in adults with common mental illness & {$[36]$} \\
\hline
\end{tabular}


Table 3 List of indicators by topic (Continued)

\begin{tabular}{|c|c|c|}
\hline Topics & Indicators & Reference \\
\hline & Perceived mental health (fair or poor) & {$[33,34]$} \\
\hline \multirow[t]{4}{*}{ Pregnancy care/ breastfeeding } & Breastfeeding (total, having ever breastfed, initiation, exclusive, by age) & {$[24,32,34]$} \\
\hline & Recommended duration of breastfeeding & {$[32]$} \\
\hline & Hospital discharge for giving birth (ICD9MC: 650) & {$[41]$} \\
\hline & $\%$ pregnant women receiving prenatal care & {$[39]$} \\
\hline \multirow[t]{3}{*}{ Hip fractures and surgical procedures } & $\begin{array}{l}\text { Proportion of patients with hip fractures recovering to their previous } \\
\text { levels of mobility/walking ability at } 30 \text { days }\end{array}$ & {$[36]$} \\
\hline & $\begin{array}{l}\text { Fractures including hip, vertebral and forearm fractures } \\
\text { (ICD9MC: 800-829) (by province, sex, age) }\end{array}$ & {$[41,43]$} \\
\hline & $\begin{array}{l}\text { Number of surgical procedures including PTCA, hip, cataract } \\
\text { (per 100,000 population) }\end{array}$ & {$[24,30]$} \\
\hline
\end{tabular}

topics or explore new areas of knowledge (yet unstudied or with a different perspective).

\author{
Abbreviations \\ AIDS: Acquired immune deficiency syndrome; AMI: Acute myocardial \\ infarction; BCG: Bacillus Calmette-Guérin; BMI: Body mass index; \\ COPD: Chronic obstructive pulmonary disease; CRDSS-E: Comisión para \\ Reducir las Desigualdades Sociales en Salud en España; CVD: Cardiovascular \\ disease; ECHI: European Core Health Indicators; GHQ-12: 12-Item General \\ Health Questionnaire; GP: General practitioner; HI: Health indicators; \\ HIV: Human Immunodeficiency Virus; HLY: Healthy Life Years: \\ ICD9MC: International Classification of Diseases, Clinical Modification; \\ IHR: International Health Regulations; NHS: National Health Service; \\ PDF: Portable document format; PHAC: Public Health Agency of Canada; \\ PINSAP: Interdepartmental and Intersectorial Public Health Plan; \\ PTCA: Percutaneous transluminal coronary angioplasty; SDG: Sustainable \\ Development Goals; SES: Socioeconomic status; SII: Slope index of inequality; \\ TB: Tuberculosis; URL: Uniform resource locator; UN: United Nations; \\ WHO: World Health Organization
}

\section{Acknowledgements}

We thank Neus Carrilero-Carrió (Agència de Qualitat i Avaluació Sanitàries de Catalunya (AQuAS), Barcelona, Spain) for support in reviewing drafts and assistance with writing.

\section{Authors' contributions}

SA performed the main bibliographic review as well as the selection and organisation of health indicators and topics. AGA supervised the whole process, contributed to the conceptualisation of the paper and provided extensive comments and improvements to the drafts. The author(s) read and approved the final manuscript.

\section{Funding}

All the activities performed were funded by the Agència de Qualitat $\mathrm{i}$ Avaluació Sanitàries de Catalunya (AQUAS) and CIBER de Epidemiología y Salud Pública (CIBERESP).

\section{Availability of data and materials}

No analysis of quantitative data was performed. Hence, data availability declaration is not applicable.

\section{Ethics approval and consent to participate}

Not applicable.

\section{Consent for publication}

Not applicable.

\section{Competing interests}

The authors declare that they have no competing interests.

\section{Author details}

${ }^{1}$ Catalan Health System Observatory, Agència de Qualitat i Avaluació Sanitàries de Catalunya (AQuAS), 81-95 (2a planta), 08005 Barcelona, Spain. ${ }^{2}$ CIBER de Epidemiología y Salud Pública (CIBERESP), Barcelona, Spain.

${ }^{3}$ Institut d'Investigació Biomèdica (IIB Sant Pau), Barcelona, Spain.

Received: 6 October 2020 Accepted: 28 January 2021

Published online: 10 March 2021

\section{References}

1. World health organization (WHO). Meeting report of the world conference on social determinants of health. Rio de Janeiro, 19-21. Geneva: WHO; 2011. p. 2012. http://www.who.int/sdhconference/resources/wcsdh_report/en/. Accessed 24 July 2019

2. Comisión para Reducir las Desigualdades Sociales en Salud en España. Propuesta de políticas e intervenciones para reducir las desigualdades sociales en salud en España. Gac Sanit. 2012:182-9.

3. Comisión para Reducir las Desigualdades Sociales en Salud en España. Análisis de situación para la elaboración de una propuesta de políticas e intervenciones para reducir las desigualdades sociales en salud en España. Madrid: Ministerio de Sanidad y Política Social; 2009. http://www.mscbs.gob. es/profesionales/saludPublica/prevPromocion/promocion/desigualdadSalud/ docs/Analisis_reducir_desigualdes.pdf. Accessed 24 July 2019.

4. Comisión para Reducir las Desigualdades Sociales en Salud en España. Avanzando hacia la equidad: propuesta de políticas e intervenciones para reducir las desigualdades sociales en salud en España. Madrid: Ministerio de Sanidad y Política Social; 2010. http://www.mscbs.gob.es/ profesionales/saludPublica/prevPromocion/promocion/desigualdadSa lud/docs/Propuesta_Politicas_Reducir_Desigualdades.pdf. Accessed 24 July 2019.

5. World Health Organization (WHO). Rio political declaration on social determinants of health Rio de Janeiro, Brazil. Geneva: WHO; 2011. p. 2012. https://www.who.int/sdhconference/declaration/en/. Accessed 24 July 2019

6. Working Group for Monitoring Action on the Social Determinants of Health. Towards a global monitoring system for implementing the Rio Political Declaration on Social Determinants of Health: developing a core set of indicators for government action on the social determinants of health to improve health equity. Int J Equity Health. 2018;17(1):136

7. Government of Catalonia. Health plan for Catalonia 2016-2020. Barcelona: Ministry of Health of Catalonia; 2016. http://salutweb.gencat.cat/web/. content/_departament/pla-de-salut/Pla-de-salut-2016-2020/documents/hea Ith-plan-catalonia_2016_2020.pdf. Accessed 24 July 2019

8. Comissió Interdepartamental de Salut. Pla interdepartamental i intersectorial de salut pública. Barcelona: Ministry of Health of Catalonia; 2017. http://sa lutpublica.gencat.cat/web/.content/minisite/aspcat/sobre_lagencia/pinsap/ 01Els_Plans/PINSAP_2017-2020/PINSAP_2017-2020-Complet.pdf. Accessed 24 July 2019

9. Cabezas-Peña C. Catalonia, Spain. Regions for Health Network (RHN). Geneva: WHO; 2018. http://www.euro.who.int/_data/assets/pdf_file/0004/3 73387/rhn-catalonia-eng.pdf. Accessed 24 July 2019 
10. Observatori del Sistema Salut de Catalunya. Efectes de la crisi econòmica en la salut de la població de Catalunya. Barcelona: Agency for Health Quality and Assessment of Catalonia; 2014. http://observatorisalut.gencat.cat/web/. content/minisite/observatorisalut/contingutsadministratius/observatori_ efectes_crisi_salut_document.pdf. Accessed 24 July 2019

11. Observatori del Sistema Salut de Catalunya. Efectes de la crisi econòmica en la salut de la població de Catalunya. Anàlisi territorial. Agency for Health Quality and Assessment of Catalonia: Barcelona; 2015. http://observatorisa lut.gencat.cat/web/.content/minisite/observatorisalut/ossc_crisi_salut/ Fitxers_crisi/Salut_crisi_informe_2015.pdf. Accessed 24 July 2019

12. Observatori del Sistema Salut de Catalunya. Desigualtats socioeconòmiques en la salut i la utilització de serveis sanitaris públics en la població de Catalunya. Agency for Health Quality and Assessment of Catalonia: Barcelona; 2017. http://observatorisalut.gencat.cat/web/.content/minisite/ observatorisalut/ossc_crisi_salut/Fitxers_crisi/Salut_crisi_informe_2016.pdf. Accessed: 13 September 2019

13. Observatori del Sistema Salut de Catalunya. Central de Resultats: Efectes de la crisi econòmica en la població infantil de Catalunya. Barcelona: Agency for Health Quality and Assessment of Catalonia; 2014. http://observatorisalut.genca t.cat/web/.content/minisite/observatorisalut/contingutsadministratius/observa tori_efectes_crisi_salut_monografic.pdf. Accessed 20 March 2020

14. Observatori del Sistema Salut de Catalunya. Central de Resultats: Evolució de la utilització de serveis i el consum de fàrmacs 2008-2015. Barcelona: Agency for Health Quality and Assessment of Catalonia; 2008. http://observa torisalut.gencat.cat/web/.content/minisite/observatorisalut/ossc_central_ resultats/informes/fitxers_estatics/MONOGRAFIC_25_CRISI_EVOLUCIO_2 008-2015.pdf. Accessed 20 Mar 2020

15. García-Altés A, Ruiz-Muñoz D, Colls C, Mias M, Martín BN. Socioeconomic inequalities in health and the use of healthcare services in Catalonia: analysis of the individual data of 7.5 million residents. J Epidemiol Community Health. 2018;72(10):871-9.

16. Ruiz-Muñoz D, Colls C, Mias M, Martín N, García-Altés A. Desigualtats socioeconòmiques en la salut i la utilització dels serveis sanitaris públics en la població de Catalunya. Ann Med. 2017;100:172-6 https://www.academia. cat/files/499-448-FITXER/provesievidencies1.pdf. Accessed 20 Mar 2020

17. Genoveva B, Ruiz-Muñoz D, García-Altés A. Efectes de la crisi econòmica en la salut de la població de Catalunya: anàlisi territorial. Ann Med. 2016;99: 126-31 https://www.academia.cat/files/499-386-FITXER/provesievidencies. pdf. Accessed 24 July 2019

18. Health for Everyone?. OECD Health Policy Studies. Paris: OECD; 2019. https:// www.oecd-ilibrary.org/social-issues-migration-health/health-for-everyone_3 c8385d0-en. Accessed 9 Jan 2021.

19. World Health Organization (WHO). Handbook on health inequality monitoring with a special focus on low- and middle-income countries. Geneva: WHO; 2013

20. UK Department of Health. Health equity audit: a self-assessment tool. London: Department of Health, 2004: 25. https://webarchive.nationala rchives.gov.uk/20120105214155/http://www.dh.gov.uk/en/Publicationsa ndstatistics/Publications/PublicationsPolicyAndGuidance/DH_4070715. Accessed 13 Sept 2019.

21. WHO Regional Office for Europe. Health 2020: A European policy framework and strategy for the 21st century. Geneva: WHO; 2013:190. http:// www. euro.who.int/_data/assets/pdf_file/0011/199532/Health2020-Long.pdf. Accessed 24 July 2019.

22. Pencheon D. The good indicators guide: understanding how to use and choose indicators. Coventry: NHS Institute for Innovation and Improvement; 2017. https://www.england.nhs.uk/improvement-hub/publication/the-goodindicators-guide-understanding-how-to-use-and-choose-indicators. Accessed 25 Mar 2020

23. Eurostat. SDG 3. Good health and well-being. Luxembourg: European Commission. https://ec.europa.eu/eurostat/web/sdi/good-health-and-wellbeing. Accessed 8 Apr 2020.

24. ECHI-European Core Health Indicators. Luxembourg: European Commission. https://ec.europa.eu/health/indicators/echi/list_en\#id3. Accessed 8 Apr 2020.

25. Marmot M. Health inequalities in the EU - final report of a consortium. Luxembourg: Publications Office of the European Union; 2013. [https://ec. europa.eu/health//sites/health/files/social_determinants/docs/healthinequa litiesineu_2013_en.pdf]. Accessed 8 Apr 2020

26. Social Protection Committee. Indicators Sub-group. Portfolio of EU socia indicators for the monitoring of progress towards the EU objectives for social protection and social Inclusion. Luxembourg: Publications Office of the European Union; 2015. http://ec.europa.eu/social/BlobServlet?docld= 14239\&langld=en. Accessed 8 Apr 2020

27. I2sare project. Galicia, Spain profile. Regional Health Profiles in the European Union, 2010. www.sergas.es/Saude-publica/-I2SARE-Galicia. Accessed 8 Apr 2020.

28. World Health Organization (WHO). Data Management Tool. Copenhagen: WHO Regional Office for Europe. http://dmt.euro.who.int/classifications/tree/ B\#B02. Accessed 8 Apr 2020.

29. World Health Organization (WHO). 100 core health indicators (plus healthrelated SDGs). Geneva: WHO; 2018. www.who.int/healthinfo/indicators/1 00CoreHealthlndicators_2018_infogr.April 2020. Accessed 8 April 2020

30. The World Bank. Health. Data. Washington DC: The World Bank. https://data. worldbank.org/topic/health. Accessed 8 Apr 2020.

31. Observatori Social d'Andorra. Sant Julià de Lòria (Andorra): Centre d'Estudis Andorrans. Govern d'Andorra https://observatorisocial.ad/index.php. Accessed 8 Apr 2020.

32. Turrell G, Stanley L, de Looper M. Oldenburg B. Health inequalities in Australia: morbidity, health behaviours, risk factors and health services use (AlHW). Canberra; 2006. www.aihw.gov.au/getmedia/0cbc6c45-b97a-44f7-a d1f-2517a1f0378c/hiamhbrfhsu.pdf. Accessed 8 Apr 2020

33. Public Health Agency of Canada. Key Health Inequalities in Canada: A National Portrait. Ottawa: Government of Canada; 2018. http://www.canada. ca/en/public-health/services/publications/science-research-data/key-healthinequalities-canada-national-portrait-executive-summary.html. Accessed 8 Apr 2020

34. Canadian Institute of Health Information. Health Inequalities Data Tool. Ottawa: Government of Canada https://health-infobase.canada.ca/healthinequalities/data-tool/index. Accessed 8 Apr 2020

35. Institute of Health Equity. Marmot indicators release 2017. London: Institute of Health Equity; 2017. http://www.instituteofhealthequity.org/about-ourwork/marmot-indicators-release-2017. Accessed 8 Apr 2020

36. NHS England Analytical Services \& the Equality and Health Inequalities Unit. England Analysis: NHS Outcome Framework Health Inequalities Indicators. London: NHS England; 2016. http://www.england.nhs.uk/wp-content/uploa ds/2017/07/nhs-outcome-framework-health-inequalities-indicators-2016-17. pdf. Accessed 8 Apr 2020

37. Scottish Government. Long-term monitoring of health inequalities. Scottish Government: Edinburgh; 2018. http://www.gov.scot/publications/long-termmonitoring-health-inequalities-december-2018-report. Accessed 8 Apr 2020

38. Buzeti $T$, Djomba JK, Blenkuš MG, Ivanuša $M$, Klanšček HJ, Kelšin N, et al. Health inequalities in Slovenia. Ljubljana: National Institute of Public Health; 2011. http://www.euro.who.int/_data/assets/pdf_file/0008/131759/Health_ inequalities_in_Slovenia.pdf. Accessed 8 Apr 2020

39. Ministry of Health and Social Policy of Spain. Moving forward equity in health: monitoring social determinants of health and the reduction of health inequalities. Madrid: Ministry of Health and Social Policy of Spain; 2010. http://www.mscbs.gob.es/profesionales/saludPublica/prevPromocion/ promocion/desigualdadSalud/PresidenciaUE_2010/conferenciaExpertos/ docs/haciaLaEquidadEnSalud_en.pdf. Accessed 8 Apr 2020

40. Instituto Nacional de Estatística-Statistics Portugal. Indicadores Sociais 2011. Lisbon: Instituto Nacional de Estatística-Statistics Portugal; 2012. https:// censos.ine.pt. Accessed 8 Apr 2020

41. García-Calvente MM, del Río LM, Marcos-Marcos J. Guía de indicadores para medir las desigualdades de género en salud y sus determinantes. Escuela Andaluza de Salud Pública. Junta de Andalucía: Granada; 2015. http://www. easp.es/project/guia-de-indicadores-para-medir-las-desigualdades-degenero-en-salud-y-sus-determinantes. Accessed 8 Apr 2020

42. Malmusi D. Desigualtats en salut, respostes a nivell local: Polítiques per reduir les desigualtats en salut a la ciutat de Barcelona. Barcelona: Ajuntament de Barcelona; 2017. http://www.consorci.org/media/upload/a rxius/coneixement/salut-publica/2017/D_\%20Malmusi_Desigualtats_28-09-2 017.pdf. Accessed 8 Apr 2020

43. Observatorio Valenciano de la Salud. Desigualdades en Salud en la Comunidad Valenciana. Valencia: Generalitat. Conselleria de Sanitat Universal i Salut Pública; 2018. http://www.sp.san.gva.es/DgspPortal/docs/2 0180301_Desigualdades_Salud_OVS2018.pdf. Accessed 8 Apr 2020

44. United Natios (UN). Life expectancy at birth. New York: UN. http://www.un. org/esa/sustdev/natlinfo/indicators/methodology_sheets/health/life_expecta ncy.pdf. Accessed 19 Mar 2020.

45. Shryock HS, Siegel JS, Stockwell EG. The methods and materials of demography. San Diego: Academic Press; 1976. 
46. Global Health Observatory (GHO) data. Infant mortality. Geneva: World Health Organization (WHO); 2018. http://www.who.int/gho/child_health/ mortality/neonatal_infant/en/. Accessed 8 Apr 2020

47. Porta M, editor. A dictionary of epidemiology, sixth edition. Oxford: Oxford University Press; 2016. http://www.oxfordreference.com/view/10.1093/acref/ 9780199976720.001.0001/acref-9780199976720. Accessed 8 Apr 2020

48. World Health Organization (WHO). Cancer. Geneva: WHO. http://www.who. int/health-topics/cancer\#tab=tab_1. Accessed 7 Apr 2020.

49. World Health Organization (WHO). Diabetes. Geneva: WHO. http://www. who.int/health-topics/diabetes\#tab=tab_1. Accessed 7 Apr 2020.

50. World Health Organization (WHO). HIV/AIDS. Geneva: WHO. http://www. who.int/health-topics/hiv-aids\#tab=tab_1. Accessed 7 Apr 2020.

51. World Health Organization (WHO). Tuberculosis. Geneva: WHO. http://www. who.int/health-topics/tuberculosis\#tab=tab_1. Accessed 7 Apr 2020.

52. Bambra C, Gibson M, Sowden A, Wright K, Whitehead M, Petticrew M. Tackling the wider social determinants of health and health inequalities: evidence from systematic reviews. J Epidemiol Community Health. 2010; 64(4):284-91.

53. Organisation for Economic Co-operation and Development (OECD). OECD Glossary of Statistical Terms-Unemployed-ILO Definition. Paris: OECD; 2003. https://stats.oecd.org/glossary/detail.asp? ID=2791. Accessed 7 Apr 2020

54. Pigeyre M, Rousseaux J, Trouiller P, Dumont J, Goumidi L, Bonte D, et al. How obesity relates to socio-economic status: identification of eating behavior mediators. Int J Obes. 2016;40(11):1794-801.

55. World Health Organization (WHO). Obesity and overweight. Geneva: WHO. http://www.who.int/en/news-room/fact-sheets/detail/obesity-andoverweight. Accessed 7 Apr 2020

56. WHO, Tobacco and inequities Guidance for addressing inequities in tobacco-related harm Written by: Belinda Loring. 2014

57. World Health Organization (WHO). Harmful use of alcohol. Geneva: WHO. http://www.who.int/health-topics/alcohol\#tab=tab_1. Accessed 7 Apr 2020.

58. World Health Organization (WHO). Physical activity. Geneva: WHO. http:// www.who.int/news-room/fact-sheets/detail/physical-activity. Accessed 7 Apr 2020.

59. American Psychological Association (APA). Socioeconomic Status. Washinton DC. http://www.apa.org/topics/socioeconomic-status/. Accessed 6 Apr 2020.

60. Eurostat. Glossary: Material deprivation - Statistics Explained. Luxembourg: European Commission. https://ec.europa.eu/eurostat/statistics-explained/ index.php/Glossary:Material_deprivation. Accessed 6 Apr 2020.

61. Solar O, Irwin A. A conceptual framework for action on the social determinants of health. Social Determinants of Health Discussion Paper 2. Geneva: World Health Organization (WHO); 2010. p. 79.

62. Salcedo N, Saez M, Bragulat B, Saurina C. Does the effect of gender modify the relationship between deprivation and mortality? BMC Public Health. 2012;12:574

63. Regidor E, Barrio G, Bravo MJ, de la Fuente L. Has health in Spain been declining since the economic crisis? J Epidemiol Community Health. 2014; 68(3):280-2.

64. Consulting Services Limited ICF. Towards a fairer and more effective measurement of access to healthcare across the EU final. London: ICF; 2018. https://ec.europa.eu/health/sites/health/files/cross_border_care/docs/2018_ measurement_accesstohealthcare_frep_en.pdf. Accessed 6 Apr 2020

65. Ebinger JO, Hamso B, Gerner F, Lim A, Plecas A. Europe and Central Asia region. New York: World Bank; 2008. https://elibrary.worldbank.org/doi/abs/1 0.1596/25984. Accessed 6 Apr 2020

66. Eurostat. Eurostat - Tables, Graphs and Maps Interface (TGM) table. Luxembourg: European Commission; 2018. https://ec.europa.eu/eurostat/ tgm/table.do?tab=table\&init=1\&language=en\&pcode=sdg_02_10\&plugin=1. Accessed 28 Feb 2020

67. Catalan Healthcare System Observatory. Indicadors de salut comunitària. Barcelona: Agència de Qualitat i Avaluació Sanitàries de Catalunya. Departament de Salut; 2017. http://observatorisalut.gencat.cat/ca/observa tori-desigualtats-salut/indicadors_comunitaria/. Accessed 25 Mar 2020

\section{Publisher's Note}

Springer Nature remains neutral with regard to jurisdictional claims in published maps and institutional affiliations.

Ready to submit your research? Choose BMC and benefit from:

- fast, convenient online submission

- thorough peer review by experienced researchers in your field

- rapid publication on acceptance

- support for research data, including large and complex data types

- gold Open Access which fosters wider collaboration and increased citations

- maximum visibility for your research: over $100 \mathrm{M}$ website views per year

At BMC, research is always in progress.

Learn more biomedcentral.com/submissions 